\title{
EFEK ANTI INFLAMASI EKSTRAK ETANOL WORTEL (DAUCUS CAROTA L.) TERHADAP TIKUS STRAIN WISTAR (RATTUS NOVERGICUS) YANG DIINJEKSI KARAGENAN
}

\author{
Yusrin Aulia ${ }^{1}$, Fathiyah Safitri², Rahmiyah Fadilah ${ }^{3}$ \\ Rumah Sakit Muhammadiyah Lamongan
}

\begin{abstract}
ABSTRAK
Efek Anti Inflamasi Ekstrak Etanol Wortel (Daucus carota L.) terhadap Tikus Strain Wistar (Rattus Novergicus) yang Diinjeksi Karagenan. Latar Belakang: Inflamasi merupakan respon fisiologis terhadap kerusakan jaringan. Inflamasi biasa diobati dengan golongan NSAID dan kortikosteroid yang memiliki efek samping cukup banyak. Wortel mengandung flavonoid yang menghambat enzim fosfolipase dan cyclooxygenase, serta saponin yang menghambat peningkatan permeabilitas vaskuler. Tujuan: Untuk membuktikan ekstrak etanol wortel (Daucus carota L.) memiliki efek anti inflamasi terhadap tikus strain wistar (Rattus novergicus) yang diinjeksi karagenan. Metode: Penelitian eksperimental dengan The Pre and Post Test Control Group Design, menggunakan 4 kelompok: (1) kontrol, (2) perlakuan dosis $100 \mathrm{mg} / \mathrm{kgBB}$, (3) perlakuan dosis $200 \mathrm{mg} / \mathrm{kgBB}$, dan (4) perlakuan dosis $400 \mathrm{mg} / \mathrm{kgBB}$. Analisis data menggunakan uji One-Way ANOVA, HSD Tukey 5\%, korelasi Pearson, dan regresi linier. Hasil dan Diskusi: Ekstrak etanol wortel meningkatkan prosentase reduksi radang secara bermakna (ANOVA $\mathrm{p}<0,05$ ) dengan signifikansi 0,000. Hal ini diduga karena kandungan flavonoid serta saponin pada wortel. Dosis ekstrak wortel yang memberikan efek anti inflamasi paling besar pada penelitian ini adalah $400 \mathrm{mg} / \mathrm{kgBB}$. Uji regresi linier menunjukkan ekstrak wortel berpengaruh 46,6\% terhadap inflamasi. Kesimpulan: Ekstrak etanol wortel memberikan efek anti inflamasi terhadap tikus strain wistar yang diinjeksi karagenan.
\end{abstract}

\begin{abstract}
Anti Inflammatory Effect of Carrot Extract (Daucus carota L.) to Carrageenan Injected Strain Wistar Rats (Rattus novergicus). Background: Inflammation is a physiologic respon for tissue damage. To reduce inflammation, people used NSAID and steroids which caused many adverse effect. Carrot contains flavonoid which can inbibit phospholipase and cyclooxygenase ensym, also saponins which can inhibit increasing of vascular permeability. Objective: To explore out that carrot extract take anti inflammatory effect to carrageenan injected strain wistar rats. Method: This study was an experimental study with the Pre and Post Test Control Group Design and using 4 groups: (1) control, (2) treatment dose of $100 \mathrm{mg} / \mathrm{kg}$, (3) treatment dose of $200 \mathrm{mg} / \mathrm{kg}$, and (4) treatment dose of $400 \mathrm{mg} / \mathrm{kg}$. Data analysis was using One-Way ANOVA, Tukey HSD 5\%, Pearson correlation and linear regression. Result and Discussion: Carrot extract could significantly increase the inflammatory reduction percentage (ANOVA $p<0.05$ ) with a significance of 0.000 . It may cause by carrot contains flavonoid and also saponin. Optimum dose of carrot extract as anti inflammatory is $400 \mathrm{mg} / \mathrm{kgBB}$. Linear regresion test showed that carrot extract take $46,6 \%$ anti inflammatory effect. Conclusion: Carrot extract may take anti-inflammatory effect to carrageenan injected strain wistar rats.
\end{abstract}

Key words: Carrot extract, inflammation, inflammatory reduction percentage.

\section{PENDAHULUAN}

Inflamasi adalah respon fisiologis berupa perlawanan terhadap lingkungan di sekitar tubuh akibat cedera untuk memperbaiki jaringan-jaringan yang sudah terlanjur rusak dan menghancurkan agen-agen penyebab inflamasi tersebut (Bharat, et al, 2012). Obat-obatan yang sekarang ini sering digunakan sebagai analgetika dan anti-inflamasi adalah obat golongan NSAID (Non Steroidal Anti-inflammatory Drugs). Efek terapi NSAID sebagai anti-inflamasi analgetik, berasal dari kemampuannya untuk menghambat biosintesis prostaglandin yang merupakan mediator nyeri. Efek samping NSAID yang paling sering terjadi adalah tukak lambung atau tukak peptik (Goodman and Gilman, 2008).

Belakangan ini penggunaan bahan alam sebagai obat cenderung mengalami peningkatan dengan adanya isu back to nature dan krisis berkepanjangan yang mengakibatkan turunnya daya beli masyarakat terhadap obat-obat modern (Katno, 2008). Wortel merupakan tumbuhan yang kaya akan manfaat, termasuk diduga sebagai antiinflamasi. Hal ini ditunjukkan dari kandungan wortel, yaitu flavonoid, $\beta$ carotene, dan saponin yang dapat mencegah terjadinya inflamasi (Pramono, 2005). Flavonoid diduga bekerja menghambat enzim lipooksigenase dan COX (Pearson, 2005), sedangkan $\beta$-carotene akan menurunkan produksi mediator pro-inflamasi (Bai et al, 2005), dan saponin diduga dapat menghambat kenaikan permeabilitas vaskuler (Pelegrini et al, 2008) sehingga edem sebagai salah satu tanda inflamasi tidak terjadi.

Penelitian ini bertujuan untuk mengetahui efek anti inflamasi ekstrak etanol wortel (Daucus carota L.) pada tikus Strain Wistar yang diinjeksi karagenan mengetahui berapa dosis yang memberikan efek anti inflamasi paling besar. 
Diharapkan hasil penelitian ini dapat digunakan sebagai sumber rujukan tambahan dalam penelitian lanjutan tentang uji potensi wortel sebagai anti inflamasi.

\section{METODE}

\section{Alat dan Bahan}

Alat-alat yang digunakan dalam penelitian ini yaitu gelas ukur, beker gelas, batang pengaduk, pinset, kandang tikus, timbangan tikus, timbangan analitik, dan alat pletismometer. Bahan-bahan yang digunakan yaitu umbi wortel, tikus Strain wistar, suspensi 1\% karagenan dalam larutan $\mathrm{NaCl}$ 0,9\%, dan etanol 95\%.

\section{Ekstraksi Tanaman dengan Cara Maserasi}

Umbi wortel segar sebanyak $1 \mathrm{~kg}$ dikupas, dicuci, kemudian diptongong kecil-kecil, masukkan dalam blender tanpa menambahkan air. Potongan tersebut diblender hingga halus. Kemudian diekstraksi dengan etanol 95\% secara maserasi menggunakan Soxhlet extractor pada suhu kamar. Hasil ekstraksi kemudian disaring dan dipekatkan dengan rotaevaporator. Hasil yang diperoleh berupa minyak berwarna kecoklatan sebanyak 1/10 dari bahan mentah. Simpan ekstrak di dalam freezer.

\section{Pembuatan Larutan Karagenan}

Timbang $50 \mathrm{mg}$ serbuk karagenan dari kemasan dengan timbangan analitik. Larutkan dengan $\mathrm{NaCl} 0,9 \%$ sebanyak $5 \mathrm{ml}$. Ambil 0,05 $\mathrm{ml}$ dengan spuit $1 \mathrm{ml}$ untuk diinjeksikan pada satu tikus.

\section{Dosis Ekstrak Wortel}

Dosis fraksi flavonoid sebagai anti inflamasi berdasarkan penelitian Santosh, et al. pada tahun 2008 dilaporkan sebesar 25, 50, 100, 200, dan $400 \mathrm{mg} / \mathrm{kgBB}$ dan dosis > $200 \mathrm{mg} / \mathrm{kgBB}$ dinyatakan aman. Kemudian dilakukan penelitian pendahuluan oleh peneliti, ditemukan dosis ekstrak wortel sebesar $100 \mathrm{mg} / \mathrm{kgBB}, 200 \mathrm{mg} / \mathrm{kgBB}$, dan $400 \mathrm{mg} /$ $\mathrm{kgBB}$ dapat memberikan efek anti inflamasi pada tikus yang diinjeksi karagenan.

\section{Pengujian Efek Anti inflamasi}

Tikus putih diadaptasikan dengan lingkungan laboratorium selama satu minggu diberi makanan standar. Pada hari pengujian ditimbang terlebih dahulu bobotnya dan dikelompokkan secara acak. Siapkan alat pletismometer. Tarik spuit pengatur untuk memastikan titik nol air raksa dalam tabung. Tandai batas telapak kaki masing-masing tikus yang akan diukur. Ukur volume telapak kaki kanan normal masing-masing tikus dengan mencelupkannya ke air raksa sampai tanda batas, lihat kenaikan air raksa pada tabung, catat. Lakukan desinfeksi telapak kaki kanan tikus dengan menggunakan kapas alkohol.

Masing-masing telapak kaki kanan tikus disuntik dengan $0,05 \mathrm{ml}$ larutan karagenan 1\% secara subkutan dengan sudut $10-30^{\circ}$. Tunggu edem muncul selama 30 menit. Masingmasing kelompok diberi perlakuan sesuai pembagian dosis. Aquades dan ekstrak diberikan secara per oral dengan sonde. Selanjutnya volume telapak kaki kanan tersebut diukur setiap 1 jam selama 5 jam dengan cara mencelupkan kaki ke dalam alat pletismometer sampai tanda yang dibuat. Lihat kenaikan air raksa pada tabung, catat. Semua data yang diperoleh ditabulasikan (Lucia, 2011).

\section{Analisis Data}

Data yang diperoleh akan diuji dengan Uji Normalitas dan Homogenitas untuk mengetahui apakah distribusi data normal dan apakah varians yang didapat homogen. Kemudian volume telapak kaki kanan kelompok kontrol dan kelompok uji dibandingkan secara statistik dengan uji One Way Anova sehingga diperoleh suatu perbedaan yang bermakna atau tidak. Jika bermakna dihitung rata-rata prosentase reduksi radang yang terjadi pada kelompok uji dengan rumus:

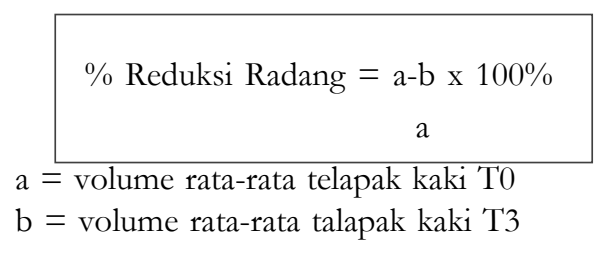

Setelah itu dilakukan Uji Tukey untuk mengetahui perbedaan yang bermakna antara masing-masing kelompok perlakuan dalam penelitian. Selanjutnya dilakukan Uji Korelasi dan Regresi untuk mengetahui hubungan dosis ekstrak wortel dengan penurunan volume edem. Uji analisis data tersebut menggunakan program SPSS 10.00 for Windows dengan nilai probabilitas 0,05 dan angka kepercayaan $95 \%$.

\section{HASIL DAN PEMBAHASAN}

Data volume edema pada jam ke-nol (T0) dan jam ketiga (T3) dapat dilihat pada tabel di bawah ini:

Tabel 1. Pengaruh Pemberian Ekstrak Etanol Wortel Terhadap Volume Edema Kaki Tikus

\begin{tabular}{|c|c|c|c|c|c|c|c|c|}
\hline \multicolumn{9}{|c|}{ 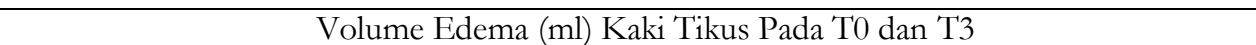 } \\
\hline $\begin{array}{l}\text { Tikus } \\
\text { Nomor }\end{array}$ & \multicolumn{2}{|c|}{ Kontrol (+) } & \multicolumn{2}{|c|}{$\begin{array}{l}100 \mathrm{mg} / \mathrm{kgBB} \\
\text { ekstrak wortel }\end{array}$} & \multicolumn{2}{|c|}{$\begin{array}{l}200 \mathrm{mg} / \mathrm{kgBB} \\
\text { ekstrak wortel }\end{array}$} & \multicolumn{2}{|c|}{$\begin{array}{l}400 \mathrm{mg} / \mathrm{kgBB} \\
\text { ekstrak wortel }\end{array}$} \\
\hline & T0 & T3 & T0 & T3 & T0 & T3 & T0 & T3 \\
\hline 1 & 0,14 & 0,57 & 0,42 & 0 & 0,42 & 0 & 0,14 & 0 \\
\hline 2 & 0,14 & 0,57 & 0,71 & 0,14 & 0,42 & 0 & 0,14 & 0 \\
\hline 3 & 0,28 & 0,57 & 0,42 & 0,14 & 0,42 & 0 & 0,28 & 0 \\
\hline 4 & 0,14 & 0,42 & 0,71 & 0,14 & 0,42 & 0 & 0,14 & 0 \\
\hline 5 & 0,14 & 0,57 & 0,42 & 0,14 & 0,42 & 0,14 & 0,28 & 0 \\
\hline 6 & 0,28 & 0,71 & 0,28 & 0 & 0,42 & 0 & 0,28 & 0 \\
\hline
\end{tabular}

(data primer) 

Dari tabel 1 dapat dihitung prosentase reduksi
radang dengan rumus:

$\%$ Reduksi Radang $=\mathrm{a}-\mathrm{b} \times 100 \%$ dimana:

$\mathrm{a}=$ volume rata-rata telapak kaki pada T0

$\mathrm{b}=$ volume rata-rata talapak kaki padaT3

sehingga didapatkan hasil sebagai berikut:

Tabel 2. Prosentase Reduksi Radang (\%)

\begin{tabular}{|ccccc|}
\hline $\begin{array}{c}\text { Tikus } \\
\text { Nomor }\end{array}$ & Kontrol $(+)$ & $\begin{array}{c}100 \mathrm{mg} / \mathrm{kgBB} \\
\text { ekstrak wortel }\end{array}$ & $\begin{array}{c}200 \mathrm{mg} / \mathrm{kgBB} \\
\text { ekstrak wortel }\end{array}$ & $\begin{array}{c}400 \mathrm{mg} / \mathrm{kgBB} \\
\text { ekstrak wortel }\end{array}$ \\
1 & -307 & 100 & 100 & 100 \\
2 & -307 & 80 & 100 & 100 \\
3 & -103 & 66 & 100 & 100 \\
4 & -200 & 80 & 100 & 100 \\
5 & -307 & 66 & 66 & 100 \\
6 & -153 & 100 & 100 & 100 \\
Rerata & $-229,5$ & 82 & 94,3 & 100 \\
\hline
\end{tabular}

(data primer)

Pada tabel 5.2 terlihat bahwa pada kelompok kontrol nilai prosentase reduksi radangnya negatif. Artinya semakin lama edem yang muncul semakin besar. Pada pemberian ekstrak etanol wortel dengan dosis yang lebih besar yaitu $400 \mathrm{mg} / \mathrm{kgBB}$ didapatkan prosentase reduksi radang sebesar $100 \%$. Pada kelompok yang diberi ekstrak etanol wortel dengan dosis $100 \mathrm{mg} / \mathrm{kgBB}$ menunjukkan prosentase reduksi radang rata-rata $82 \%$ dan pada pemberian dosis 200 $\mathrm{mg} / \mathrm{kgBB}$ didapatkan rata-rata sebesar 94,3\%. Hal ini menunjukkan bahwa semakin besar dosis yang diberikan, prosentase reduksi radang juga semakin besar.

Hasil uji Normalitas menunjukkan bahwa pada kolom uji shapiro-Wilk (lampiran) terlihat bahwa dari variabel yang akan diuji, hasil penelitian menunjukan nilai signifikansi prosentase reduksi radang $(0,079)$ lebih besar dari $\mathrm{p}(0,05)$ yang berarti bahwa distribusi data bersifat normal.

Untuk mendeteksi ada atau tidaknya heterogenitas dilakukan dengan menggunakan uji kesamaan ragam yaitu uji Levene (Levene test homogeneity of variances). Hasil uji Homogenitas (lampiran) menunjukkan bahwa nilai Signifikansi dariuji Levene sebesar $(0,096)$ lebih besar dari p $(0,05)$ yang berarti varian data prosentase reduksi radang pada masing-masing perlakuan bersifat homogen. Selanjutnya dapat dilanjutkan untuk uji One-way ANOVA pada tahap berikutnya, karena asumsi homogenitas ragam data telah terpenuhi.

Berdasarkan hasil uji One way ANOVA (lampiran) menunjukkan bahwa nilai Sig sebesar 0,000. Nilai tersebut lebih kecil dari $\mathrm{p}(0,05)$ sehingga dapat disimpulkan bahwa terdapat pengaruh perlakuan pemberian ekstrak etanol wortel terhadap prosentase reduksi radang tikus strain wistar secara bermakna.

Hasil uji pembandingan berganda (Tukey's Test) (lampiran) menunjukkankelompok kontrol memiliki perbedaan yang bermakna dengan semua kelompok perlakuan. Hal ini dibuktikan dengan nilai signifikan masingmasing kelompok sebesar 0,000 lebih kecil dari $\mathrm{p}(0,05)$.
Namun tidak didapatkan perbedaan yang bermakna antara kelompok perlakuan P1 (diberi ekstrak etanol wortel dosis $100 \mathrm{mg} / \mathrm{kgBB}$ ) dengan kelompok perlakuan P2 (diberi ekstrak etanol wortel dosis $200 \mathrm{mg} / \mathrm{kgBB}$ ) karena nilai signifikan lebih besar dari $\mathrm{p}(0,05)$ yaitu 0,968 . Begitu juga pada kelompok perlakuan P2 dan P3 (diberi ekstrak etanol wortel dosis $400 \mathrm{mg} / \mathrm{kgBB}$ ) nilai signifikan sebesar 0,997 lebih besar dari $\mathrm{p}(0,05)$. Serta pada kelompok P1 dan P3 nilai signifikan 0,910 lebih besar dari $\mathrm{p}(0,05)$. Hal ini menunjukkan bahwa tidak ada perbedaan yang bermakna pada kelompok perlakuan P1, P2, dan P3.

Pada uji korelasi pearson (lampiran) di dapatkan nilai koefisien korelasi $(r)$ sebesar $r=0,683$ yang berarti terdapat hubungan yang kuat antara dosis ekstrak etanol wortel dengan prosentase reduksi radang. Nilai positif pada koefisien korelasi menunjukkan bahwa dosis ekstrak etanol wortel dan prosentase reduksi edema berbanding lurus. Artinya, semakin besar dosis ekstrak etanol wortel yang diberikan, maka semakin besar pula prosentase reduksi radangnya.

Persamaan regresi yang di gunakan untuk menentukan pengaruh antara dosis ekstrak etanol wortel pada prosentase reduksi radang adalah :

$$
\begin{aligned}
& \mathrm{Y}=-106,42+0,67 \mathrm{X} \\
& \text { Keterangan }: \\
& \mathrm{Y}=\text { Prosentase reduksi radang } \\
& \mathrm{X}=\text { Dosis ekstrak etanol wortel } \\
& \mathrm{R} 2=0,466
\end{aligned}
$$

Persamaan tersebut sesuai dengan tabel Anova Regresi (lampiran) dimana nilai sig anova regresi $=0,000<\mathrm{p}(0,05)$ yang berarti model regresi cocok secara bermakna. Hal tersebut didukung pula pada uji t tabel coefficient (lampiran) yang menunjukkan bahwa nilai sig (constanta) $=0,006$ dan sig $($ dosis $)=0.000$ yang berarti lebih kecil dari nilai $\mathrm{p}(0,05)$. Nilai R2 yang terbentuk pada persamaan tersebut yaitu 
0,466, artinya pengaruh dosis ekstrak etanol wortel terhadap peningkatan prosentase reduksi radang adalah sebesar 46,6\%. Sedangkan 53,4\% sisanya dipengaruhi oleh faktor lain di luar penelitian ini.

Berdasarkan hasil penelitian dan analisis data menunjukkan bahwa pemberian ekstrak etanol wortel berpengaruh terhadap prosentase reduksi radang pada tikus strain wistar yang diinjeksi karagenan.

Kaki tikus yang diinjeksi dengan karagenan $1 \%$ sebanyak $0,05 \mathrm{ml}$ akan menyebabkan edema. Hal ini sesuai dengan penelitian Rustam (2007) tentang efek anti inflamasi yang menggunakan penginduksi karagenan $1 \%$ sebanyak $0,05 \mathrm{ml}$. Edema terbentuk setelah tiga puluh menit. Hal ini sesuai dengan penelitian Amutha et al (2012) yang menyebutkan bahwa karagenan menimbulkan edem 15 - 30 menit setelah diinjeksikan.

Penelitian ini membuktikan bahwa terdapat perbedaan prosentase reduksi radang antara kelompok kontrol dengan kelompok perlakuan. Pada kelompok P3 prosentase reduksi radang pada T3 mencapai 100\%. Peningkatan prosentase reduksi radang pada $\mathrm{P} 1, \mathrm{P} 2$, dan $\mathrm{P} 3$ diduga karena pemberian ekstrak etanol wortel. Hal ini sesuai dengan penelitian terdahulu oleh Vishwanath K.P. et al (2012) yang membuktikan ekstrak aqueous wortel memberikan efek anti inflamasi terhadap tikus model colitis.

Ekstrak etanol wortel mengandung senyawa yang bekerja sebagai anti inflamasi, yaitu flavonoid dan saponin (Vishwanath K.P. et al, 2012). Kandungan flavonoid pada wortel sebanyak 5,11\%. Mekanisme anti inflamasi flavonoid diduga melalui jalur penghambatan enzim fosfolipase, enzim COX, dan/atau enzim lipooksigenase. Proses tersebut akan menghambat release prostaglandin sebagai mediator inflamasi sehingga edem tidak lagi terjadi (Pearson, 2005). Hal ini sejalan dengan penelitian Santosh et al (2008) tentang aktivitas anti inflamasi fraksi flavonoid. Pada penelitiannya dibuktikan bahwa fraksi flavonoid dari bunga boroco mulai dosis 25 , 50, 100, 200, dan $400 \mathrm{mg} / \mathrm{kgBB}$ menurunkan volume edema kaki tikus secara bermakna.

Saponin terdapat pada wortel sebanyak 41,61\% (Okukpe et al, 2012). Sebagai anti inflamasi, saponin diduga berinteraksi dengan banyak membran lipid, seperti fosfolipid yang merupakan prekursor prostaglandin dan mediator inflamasi lainnya (Pelegrini et al, 2012). Hal ini didukung oleh penelitian sebelumnya oleh Hidayati (2008) yang membuktikan bahwa ekstrak saliara yang mengandung saponin memiliki efek anti inflamasi terhadap tikus yang diinduksi karagenan.

Semua dosis ekstrak etanol wortel yang digunakan pada penelitian ini memberikan efek anti inflamasi. Hal ini sejalan dengan penelitian Vasudevan et al (2006) yang menyatakan dosis ekstrak etanol biji wortel sebagai anti inflamasi adalah $100 \mathrm{mg} / \mathrm{kgBB}, 200 \mathrm{mg} / \mathrm{kgBB}$, dan 400 $\mathrm{mg} / \mathrm{kgBB}$. Ekstrak biji wortel sendiri memiliki kandungan yang sama dengan ekstrak umbi wortel yang digunakan pada penelitian.

Namun tidak didapatkan perbedaan yang bermakna antara masing-masing kelompok perlakuan. Hal ini menunjukkan bahwa dosis yang digunakan dalam penelitian ini rentangnya terlalu sempit. Selain itu dosis yang digunakan pada kelompok perlakuan P1 terlalu besar sehingga perbedaan dengan kelompok kontrol cukup jauh. Untuk penelitian selanjutnya bisa digunakan dosis pada kelompok perlakuan P1 yang lebih kecil dan selisih jarak antar dosis perlakuan lebih jauh. Dosis maksimal yang digunakan adalah tidak lebih dari $2000 \mathrm{mg} / \mathrm{kgBB}$ karena menurut Vasudevan et al (2006) dosis ekstrak etanol biji wortel yang diberikan per oral lebih dari $2000 \mathrm{mg} / \mathrm{kgBB}$ merupakan dosis letal bagi tikus.

Dengan uji regresi, penelitian ini menunjukkan pengaruh dosis ekstrak etanol wortel terhadap prosentase reduksi radang sebesar 46,6\%, artinya peningkatan reduksi radang pada kaki tikus dipengaruhi oleh dosis ekstrak etanol wortel sebesar $46,6 \%$ dan sisanya sebesar 53,4\% dapat di pengaruhi oleh faktor lain baik endogen maupun eksogen. Faktor endogen bisa berupa peningkatan sitokin anti inflamasi yaitu IL-10 dan TGF- $\beta$ yang dikeluarkan hampir bersamaan dengan sitokin pro inflamasi saat terjadi cedera (Sultani et al, 2012). Selain itu bisa juga disebabkan oleh anti inflamasi endogen, seperti glukokortikoid, porfirin, dan melanocortin. Glukokortikoid merupakan anti inflamasi endogen yang paling kuat yang bekerja menghambat release prostaglandin. (Lawrence et al, 2002). Sedangkan faktor eksogen bisa berupa penurunan stabilitas karagenan yang disebabkan proses autohidrolisis. Laju autohidrolisis tersebut akan bertambah pada kenaikan temperatur (Imeson, 2009). Proses inflamasi sendiri akan meningkatkan temperatur karena adanya peningkatan aliran darah pada daerah inflamasi serta pengeluaran mediator-mediator pro inflamasi yang seperti IL-1 dan TNF- $\beta$ (Price \& Wilson, 2006).

Berdasarkan tabel uji linier regresi (lampiran) diketahui bahwa pengaruh dosis ekstrak etanol wortel berpengaruh positif terhadap prosentase reduksi radang pada kaki tikus yang diinjeksi karagenan. Artinya semakin besar dosis yang diberikan, prosentase reduksi radang juga akan semakin meningkat. Hal ini sejalan dengan penelitian Santosh et al (2008).

Kelemahan penelitian ini adalah dosis yang digunakan rentangnya terlalu sempit sehingga bila dilihat pada analisis data tidak ada perbedaan antara kelompok P1, P2, dan P3. Selain itu karagenan yang digunakan stabilitasnya mudah terganggu oleh suhu dan $\mathrm{pH}$.

\section{SIMPULAN}

Ekstrak etanol wortel (Daucus carota L.) dapat memberikan efek anti inflamasi terhadap tikus strain wistar yang diinjeksi karagenan. Dosis ekstrak etanol wortel (Daucus carota $L$.) yang memberikan efek anti inflamasi paling besar pada penelitian ini adalah $400 \mathrm{mg} / \mathrm{kgBB}$, dengan prosentase reduksi radang mencapai $100 \%$.

\section{DAFTAR PUSTAKA}

Anderson, Kat, dkk. 2010. Plants Database. United States Department of Agriculture. (http://plants.usda.gov/ team.html)

Apsari, Adyuta. 2007. Pengaruh Pemberian Minyak Buah Merah (Pandanus conoideus) sebagai Anti-Inflamasi pada Tikus (Rattus Novergicus) Strain Wistar 
Bai, et al. 2005. beta-Carotene inhibits inflammatory gene expression in lipopolysaccharide-stimulated macrophages by suppressing redox-based NF-kappaB activation. (http:// www.ncbi.nlm. nih.gov/pubmed/16155409)

Barnes PJ. 2010. Mechanisms and Resistance in Glucocorticoid Control of Inflammation. Journal Steroid Bioche Mol Biol. (120):76-85.

Bharat et al. 2012. Inflammation, Lifestyle, and Chronic Disease: The Silent Link.United States: CRC Press.

Cahyono, Bambang. Ir. 2006. Wortel: Teknik Budidaya dan Analisis Usaha Tani. Jogjakarta: Kanisius. (2): 15-23

Calder, Philip C. 2006. n-3 Polyunsaturated Fatty Acids, Inflammation, and Inflammatory Diseases. The American Journal of Clinical Nutrition Vol. 83 No. 6

Goodman and Gilman. 2008. The Pharmacological Basis of Therapeutics. 11th edition. p. 666-670.

Gunawan, Sulistia Gan. 2009. Farmakologi dan Terapi. Edisi 5. Jakarta: Balai Penerbit FK UI. (14): 230-246.

Hidayati, dkk. 2008. Kandungan Kimia dan Uji Antiinflamasi Ekstrak Etanol Lantana camara L. pada Tikus Putib (Rattus norvegicus L.) Jantan. Bioteknologi 5 (1): 10-17

Imeson, A.P. 2009. Handbook of Hydrocolloids: Carrageenan. UK: Woodhead Publishing. (5): 91-93.

Joany, et al. 2012. Anti-inflammatory effects of selective glucocorticoid receptor modulators are partially dependent on up-regulation of dual specificity phosphatase. Br J Pharmacol. Feb 2012; 165(4b): 1124-1136

Katno. 2008. Tingkat Manfaat Keamanan dan Efektifitas Tanaman Obat dan Obat Tradisional. B2P2TO-OT Balitbangkes Depkes RI.

Levinson RD. 2007. Immunogenetics of ocular inflammatory disease.Tissue Antigens. (69):105-12.

Lucia. 2011. Eksperimen Farmakologik: Orientasi Preklinik pada Hewan. Surabaya: Sandira Surabaya. p. 254-255

Med J, Saudi. 2004. Awareness and Frequency of Potential Side Effects on Nonsteroidal Anti-Inflammatory Drugs Among the Jordanian Patient Population. PubMed United States National Library of Medicine.

Necas, J. 2013. Carrageenan: a review. Veterinarni Medicina, 58, (4): 187-205

Okukpe, et al. 2012. Investigation of Phytohormonal Potential of Some Selected Tropical Plants. Research Journal of Medicinal Plant, 6: 425-432.

Pearson, et al. 2005. Flavanols and Platelet Reactivity. Clinical \& Developmental Immunology. March 2005; 12(1): 1-9

Pedro, et al. 2012. Structural Analysis of Flavonoidsand Related Compounds - A Reviewof Spectroscopic Applications. Phytochemicals - A Global Perspective of Their Role in Nutritionand Health, (2): 33-44

Poetker DM, Reh DD. 2010. A comprehensive review of the adverseeffects of systemic corticosteroid. Otolaryngol Clin $N$ Am. (43):753-68.

Porth, Carol. 2010. Essentials of Pathophysiology: Concepts of Altered Health States, (3): 51-60

Pramono, Suwijiyo. 2005. Efek Antiinflamasi Beberapa Tumbuhan Umbelliferae. Hayati Vol. 12 No. 1. p.7-10

Price, Sylvia dan Loraine Wilson. 2006. Patofisiologi Konsep Klinis Proses-Proses Penyakit. Jakarta: EGC. (4): 58-59

Rachman, Adetiya. Dian Histafarina. 2010. Potensi Sayuran Wortel dan Produk Olahannya sebagai Pangan Fungsional. Seminar Nasional Pangan Fungsional.
Rustam, Erlina, dkk. 2007. Efek Anti Inflamasi Ekstrak Etanol Kunyit (Curcuma domestica Val) pada Tikus Putih Jantan Galur Wistar. Jurnal Sains dan Teknologi Farmasi Vol. 12 No. 2. p.112-115

Santosh et al. 2008. Anti- inflammatory Activity of An Isolated Flavonoid

Fraction from Celosia argentea Linn. Journal of Medicinal Plants Research Vol. 2(3), pp. 052-054.

Shaswati, et al. 2013. Chronic Inflammation: Molecular Pathophysiology, Nutritional and TherapeuticIntervention. CRC p.305-312

Siswandono dan B. Soekardjo. 2008. Kimia Medisinal. Surabaya: Airlangga University Press. hal: 61-62.

Smoak KA, Cidloski JA.2008. Glucocorticoid signaling in bealth and disease. The Hypothalamus-Pituitary-Adrenal Axis. 33-53.

Soeroso, Joewono, dr. 2012. Bone Inflammation in Rheumatoid Arthritis and Ankylosing Spondylitis. Jurnal Universitas Airlangga.

Sultani et al. 2012. Anti-Inflammatory Cytokines: Important Immunoregulatory Factors Contributing to Chemotherapy-Induced Gastrointestinal Mucositis. Chemotherapy Research and Practice Volume 2012 (2012), Article ID 490804, 11 pages.

Supranto, J. 2007. Teknik Sampling untuk Survei dan Eksperimen. Rineka Cipta. Jakarta. hal: 217.

Syarif A, Ari E, Arini S, dkk. 2008. Farmakologi dan Terapi. Edisi lima. Jakarta: Balai Penerbit FKUI.

Vasudevan et al. 2006. Antinociceptive and Anti Inflammatory Properties of Daucus carota Seeds Extract. Journal of Health Science, 52(5)598-606

Vishwanath, Mithun. 2012. Anti-Inflammatory Effect of Daucus Carota Root on Experimental Colitis in Rats. International Journal of Pharmacy and Pharmaceutical SciencesVol. 4, Issue 1

Zeng, Q.Y. 2008. Effect of tumor necrosis factor a on disease arthritis reumatoid. Journal of Experimental Medicine. 